\title{
Overcoming The Biological Trap: A Study Of Ernest Hemingway's A Farewell To Arms And The Old Man And The Sea
}

\author{
Tsavmbu, Aondover Alexis (Corresponding Author) \\ Federal University Dutsin-ma, Nigeria \\ E-mail: atsavmbu@fudutsinma.edu.ng \\ Amase, Emmanuel Lanior \\ Federal University Dutsin-ma, Nigeria \\ E-mail: eamase@fudutsinma.edu.ng \\ Kaan, Aondover Theophilus \\ Federal University Dutsin-ma, Nigeria \\ E-mail: akaan@fudutsinma.edu.ng
}

Doi:10.7575/aiac.alls.v.5n.2p.166

Received: 08/03/2014

URL: http://dx.doi.org/10.7575/aiac.alls.v.5n.2p.166

Accepted: 15/04/2014

\begin{abstract}
Ernest Hemingway is one of the greatest writers that America has produced. His works have indeed, contributed immensely in shaping the literary path in his country. All his novels are tragedies and his heroes tragic heroes because he is always conscious of man's mortality. In this paper, we have undertaken a critical study of Hemingway's exploration of the theme of 'the trapped man' in A Farewell to Arms and The Old Man and the Sea. Hemingway believes that man is biologically trapped and doomed to suffer and die. This is clearly demonstrated by Frederick Henry in A Farewell to Arms. However, in The Old Man and the Sea, Santiago, the protagonist has demonstrated that though man is a victim of a hostile universe, he is not made for defeat. Santiago's actions prove that with a dogged determination and focus, it is possible for humanity to overcome the biological trap and achieve success in life. We believe that this important lesson lays credence to the utilitarian value of literature to the society. This prerequisite for overcoming the biological trap is a necessary antidote because the trap does not only hang over Hemingway's characters but humanity as a whole.
\end{abstract}

Keywords: Overcoming, biological trap, tragic heroes, trapped man, hostile universe, victim

\section{Introduction}

All of Hemingway's novels are tragedies and his heroes, tragic heroes. This, we believe, is because Hemingway is always conscious of man's mortality. For him, the human being is doomed because he believes that man is so biologically trapped such that whatever he does on earth, and not withstanding his best efforts, he must ultimately either lose or die; or suffer both at the same time. That is why Marca (2010) affirms Hemingway's belief that the human race is irretrievably lost by explaining why Hemingway creates protagonists who are, "struggling to come to terms with how they fit into the complicated world they were born into and looking for meaning or cause in their lives" (Marca, 2010).

As a result of Hemingway's preoccupation with the biological trap that holds all human beings captive, “... some critics have accused him of being obsessed by death, but we believe that he is simply debriefing life as he experiences and understands it" (Curry, 1988). Curry (1988) affords us an insight into Hemmingway's chequered life that was characterised by an unhappy childhood during which he is reported to have professed hatred for his mother. We also have glimpse of a life during which Hemingway experienced the disasters of warfare at a tender age, endured a compendium of failed marriages and witnessed several other painful experiences including suicide by members of his family including his father and later even himself(Wikipedia, http://schools-wikipedia.or/wple/ernest_Hemingway.htm, 2013). With such a background, one can understand the apocalyptic, nihilistic and woebegone perception of life that characterises Hemingway's works.

It is therefore believed that Hemingway used autobiographical details as framing devices about life in general—not only about his life. For example, it is postulated that Hemingway used his experiences and drew them out with "what if" scenarios: "what if I were wounded in such a way that I could not sleep at night? What if I were wounded and made crazy, what would happen if I were sent back to the front?" (Benson, 1989). Mellow agrees with this position when he says, "His wartime experiences formed the basis for his novel A Farwell to Arms" (Mellow, 1991). That is why it is important not to expect a happy ending while reading any of Hemingway's works since there is a doom that hangs over all his novels from the very first chapter. However, it is important to observe that such foreboding atmosphere does not make the reader lose interest in the story because Hemingway maintains a life-death tempo that sustains interest and brings the reader to the last chapter uplifted; only to be cast down into the depths of sadness. 
Although the above analogy aptly captures the essence of Hemingway's creativity, especially as regards the presentation of his protagonists, there appears to be a subtle, yet remarkable difference between his other protagonists and that in The Old Man and The Sea who embodies the positive virtues necessary for human development; virtues that are either completely missing or found in very limited amounts in Hemingway's other protagonists, particularly in the protagonist of A Farwell to Arms. This is why we believe The Old Man and the Sea stands out when compared with his other works and contains the recipe for overcoming the biological trap.

It is therefore not surprising that Hemingway did not get the Nobel Prize for Literature until he wrote The Old Man and the Sea. In fact, from the wordings that accompanied the award, it is clear that this novel more than any of Hemingway's other works, tipped the scales in his favour (Meyers, 1985). The Wikipedia, the free encyclopedia, supports this position when it posits that in 1954, when Hemingway was awarded the Nobel Prize for Literature, it was for "his mastery of the art of narrative, most recently demonstrated in The Old Man and the Sea" (Wikipedia, http://en.wikipedia.org/wiki/ernest_Hemingway\#cite-ref-162, 2010). Apart from the Nobel Prize, we are also told that "The Old Man and the Sea became a book-of-the-month selection, made Hemingway an international celebrity, and won him the Pulitzer prize in May 1952" (Desnoyers, 2011).

\section{The Biological Trap in Hemingway's A Farewell to Arms}

A Farwell to Arms is the story of Frederick Henry, a young American volunteer for the Italian ambulance service in the First World War. Up near the Austrian and Italian fronts, he meets and falls in love with Catherine Barkley, a British nurse and for the first time since he was born, begins to find more meaning in life. The events of the war however, lead to disillusionment; he is wounded in the knee by a shell, and later he is nearly killed by the Italian battle police while taking part in a general retreat. He then decides to desert the army and take Catherine with him to Switzerland.

Although several writers have written about World War 1, Hemingway's A Farwell to Arms has distinguished him as a writer of extraordinary freshness, power and indeed as one of the makers of a new American fiction. Commenting on the star features of this novel, Carlos Baker states that "Hemingway managed to catch and hold in his novel a set of attitudes towards war and human love which are essentially ageless" (Baker, 1964).

His characters in this novel are aware of the fact that nature has conspired against man; an affirmation of the biological trap. The novel makes it clear that war is evil as it causes death to humanity; but because man is biologically trapped and destined to die, he embraces war instead of love. When Catherine lies in pains in the hospital in Switzerland, Frederick Henry says, "it's just nature giving her hell" (227). This means that even the war that is being fought is nature's grand design for man to experience pain and eventually the ultimate end (death).

Frederick Henry, Hemingway's hero has discovered the emptiness of the trapped man's life with his symbolic encounter with a dog nosing at empty cans on a refuse heap in Chapter Forty-One of the novel. While Catherine's labour continues at the hospital, Henry goes down a street to have breakfast. He comes across a dog nosing at an empty can on a refuse heap and he asks the dog, "what do you want?....There isn't anything, dog" (223). This incident is symbolic of the emptiness that the trapped man experiences.

Throughout the novel therefore, Henry is searching for some consistent system of values to which he can adhere; unfortunately, it is clear he finds none other than the realisation that man is trapped right from birth. When he goes on leave for instance, he spends most of his time visiting brothels and also drinking heavily. At this point in Henry's life, drink and sex are both escape symbols. He is trying to obliterate the meaninglessness and emptiness of this world of war and death. Therefore, he devotes himself to the fulfillment of these appetites. This desire to satisfy ephemeral appetites is typical of Hemingway's heroes who are always conscious of human mortality and are thus prepared to make the best use of their period of existence. Frederick Henry is also afraid of darkness because it is like the darkness of death. He is restless and cannot face sleeping in a dark room and this fear forces him to search for some type of sensation during the night.

A Farewell to Arms is a tragedy and some critics refer to it as "a narrative of doom" (Baker, 1964: 139). Hemingway himself believes that because man is trapped, his life can have only one end. He is quoted by Baker to have once stated, "The fact that the book was a tragic one did not make one unhappy since I believed that life was a tragedy and knew it could only have one end" (Baker, 1964: 139). Man's life is meant to end tragically. Therefore the lives of the main characters in this novel are tales of woes.

At Frederick's first meeting with Miss Barkley, she talks of her young fiancé who was killed while fighting in the Somme. During their first conversation, Catherine Barkley makes a statement that gains significance throughout the novel. Speaking of her late fiancé she says, "Then of course he was killed and that was the end of it" (18). It was indeed the end of his life and also the end of their love affair. Frederick Henry protests and Catherine dismisses the comment by repeating that death ends everything. Frederick does not accept this view completely at the time, until at the end of the novel when Catherine herself dies that it dawns on him that death is indeed the end of all things.

As we pointed out earlier in this paper, Hemingway believes that man is biologically trapped; therefore, all his efforts to be happy are often thwarted by fate. Henry falls in love with Catherine and hopes to marry and make a family, but this is never to be. Miss Ferguson, a fellow nurse and friend of Catherine, can see the end of the relationship from the beginning. When Henry asks her if she would attend their wedding, she replies, "You will never get married.... You'll die then. Fight or die. That's what people do" (80). 
Henry's relationship with Catherine results to pregnancy and she breaks the news to him thus: "I am going to have a baby, darling. It's almost three months along" (101). Even though they planned to get married one day, the pregnancy is not expected at this point. She had tried to avoid getting pregnant but to no avail. She states: "I did everything. I took everything but it didn't make any difference" (101). Catherine and Henry suddenly feel trapped with the coming of the pregnancy and the possibility of having a baby they are not yet prepared for. Conscious of the fact that Henry is obviously worried about this discovery, Catherine asks: "And you don't feel trapped?" (102) And Henry replies, "May be a little. But not by you.... You always feel trapped biologically" (102). When Henry says he is brave and "nothing ever happens to the brave" (103), Catherine replies that "They die of course" (103). This discussion shows clearly that the two lovers know that man is trapped by nature; that the misfortunes that man faces are indeed merely a necessary prelude to the ultimate end - death.

The night Henry is to return to the warfront after his recovery from leg injuries, he and Catherine spend some good time together at a hotel near the train station in Milan. In spite of the good time they have together, Henry suddenly remembers how short man's life is and quotes Andrew Marvel's words,

"And always at my back I hear

Time's winged chariot hurrying near" (113).

Again, when Catherine's labour starts at the hotel and she is to be rushed to the hospital, the elevator operator cannot be found. When eventually that challenge is overcome, it is again difficult getting a taxi to convey her to the hospital in time. These are all indications of nature's conspiracy against the trapped man.

Also, as Catherine's labour becomes abnormally prolonged, Henry becomes uneasy as it dawns on him that the trap in which they are is gradually being tightened. He therefore laments, "Poor, poor dear Cat. And this was the price you paid for sleeping together. This was the end of the trap. This was what people got for loving each other" (227). Henry realises that no matter what man does, he eventually gets caught up in the trap that nature has set for him. He regrets "so now they got away with anything" (227). Henry has a premonition of Catherine's death. He can feel it but has no power to stop it.

In the end Catherine cannot deliver the baby on her own so she has to undergo a fatal caesarean section. The baby is removed dead and Catherine also dies due to complications from the surgery - a further confirmation of the trap.

Also worthy of note in this novel is the strong emphasis on the rain symbolism, especially in Chapter Nineteen of the book. Rain is used as a symbol of tragedy or death and destruction. We realise that Catherine is afraid of the rain because for her, it is symbolic of death. She sometimes sees herself as being dead in the rain. Man is thus helpless in the face of death. The inability of man to help himself shows that he is a victim of a hostile universe.

Hemingway continues his use of the rain symbolism in exploring the theme of the trapped man by associating tragic events with rainfall. The retreat of the tired Italian troops is halted by rain and later turns into a disaster, the parting of Catherine and Henry at the railway station as he heads for the front again is also done while it is raining. Henry's escape with Catherine to Switzerland, where Catherine later dies after a caesarean operation, is done while it is raining and more importantly, it is raining at the time of Catherine's death in the hospital.

Frederick Henry feels trapped after he learns that Catherine is pregnant. This feeling has a wider application because Hemingway is implying here that ultimately, man is trapped in almost everything he does. All he can do is to accept his fate with stoicism, just as Catherine faces her death at the end of the novel.

In Book III of the novel we are confronted with many more images suggestive of death and destruction, barrenness and sterility. Book III speaks of hostility, the dead, the crushed and the rain. We are introduced to the town of Caporetto where the retreat turns into anarchy, confusion and disorder. Even Henry and Bonello, one of his drivers, kill a sergeant that is retreating with them. This shows how chaos has taken over from reason, thus sending thousands to their graves. The killing of Aymo by his own countrymen is equally another indication of the senselessness and confusion of the war. Equally appalling is the insanity demonstrated by the Italian battle police who execute military officers.

In the last chapter of the novel, Frederick Henry finally learns in a hard way that there are indeed forces against which he cannot fight, that Catherine's death is the trap that he felt earlier. He also learns that mortal man must be totally independent in this world. If you trust in another mortal being, you can easily be defeated when the person bows to death, like Catherine. Thus he comes to terms with the idea of man's defeat and futility of life.

Frederick had hitherto doubted the finality of death. Now however, he knows that the only value in death is man's knowledge that death is inevitable; it must come when it must come. Frederick's desertion of the army was to bid farewell to arms and the war. It is rather ironical that because man is trapped, his action is of double effect. Just as he bids farewell to arms and the war, he also bids farewell to Catherine's arms.

\section{The Biological Trap in Hemingway's The Old Man and The Sea}

The Old Man and the Sea is a very interesting story of a Cuban fisherman's fight with a great fish. Santiago, simply referred to as the old man, has gone on fishing expeditions for eighty four days without a catch. His bad luck has become so legendary that he is not only described as "salao" (a person of incurable bad luck) but the boy that used to go fishing with him as a trainee fisherman is withdrawn on the fortieth day by his parents and attached to a luckier boat. Due to his prolonged misfortune, the old man no longer can feed himself and would have died of hunger but for the intervention of his former apprentice, who though withdrawn from the old man, retains deep affection for his former 
master and makes it a point of duty to care for the old man and provide him food and bait. In fact, the old man is so poor that no one would steal his property even if he carelessly leaves it outside.

On the eighty-fifth day, the old man decides that the number eighty-five is usually a lucky number so he is determined to make the magic of this number work for him. He therefore goes out to fish with more determination than ever before and dares into waters or parts of the ocean rarely ventured into by other fishermen and here he gets the biggest catch of his life; and what a catch considering his many years on earth!

The old man battles with the great fish for three days and just when he thinks he has won the battle, sharks appear to deprive him of his hard won prize! He resolves to fight the sharks as well; saying, "Man is not made for defeat.... A man can be destroyed but not defeated" (75). With this determination, he kills four sharks and injures two others badly before he runs out of weapons but continues to fight with his oar even as darkness catches up with him and he can barely see his fish being torn away with impunity. In fact, we are told that he fights so much that, "he felt a strange taste in his mouth... It was slippery and sweet and he was afraid of it for a moment. But there was not much of it" (86).

Santiago finally arrives home when everyone is asleep to be attended by the boy that has remained loyal to him all along and to the admiration of all the other fishermen whose perception of the old man changes forever.

It is true that even in this novel the biological trap is evident in Santiago's battle with the elements. We have the feeling of man being the hunted specie rather than the hunter; a recurrent thematic preoccupation in Hemingway's works. However, it is significant to note that unlike what we see in most of his works particularly his A Farewell to Arms, Santiago has been excellently depicted. Here, we have a protagonist that has refused to resign to fate; Santiago has refused to meekly accept whatever nature dishes out to him. On the contrary, he has fought back every step of the way. Man is portrayed here as standing up to denounce, in the loudest terms possible, the docile posture of Hemingway's heroes in his other works; a posture that irrevocably precipitates their destruction. In this novel, man's philosophy of life is captured on page 75 where the old man says, "But man is not made for defeat.... A man can only be destroyed but not defeated". It is this philosophy that empowers the old man to triumph at the end. This same determination can make any man overcome the biological trap no matter how formidable it may be.

It is true that Santiago does not succeed in coming home with the whole fish but his success can be measured at various levels: at the first level, we can say Santiago has succeeded because he has permanently laid to rest the belief that he is "salao". The fish he finally captures becomes a sort of tourist attraction even among fellow fishermen despite the fact that only the skeleton and the head survive to testify to its enormity. We are told that early the following morning, "many fishermen were around the skiff looking at what was lashed beside it, and one was in the water, his trouser rolled up, measuring the skeleton with a length of line" (89). At the second level Santiago has succeeded because as a result of his latest achievement, the old man's former trainee, who was forced by his parents to abandon Santiago, decides to follow his mind and reunite with his master regardless of whatever anybody would think saying, "the hell with luck,... I'll bring the luck with me' (90). When asked what his family would say he laconically replies, "I do not care... we will fish together now for I still have much to learn" (90). This is a tacit admittance by the boy that the old man is the sole repository of knowledge and only from this fountain of knowledge can he draw enough experience to be a successful fisherman one day. At the third level and most significantly, Santiago has not abandoned fishing due to this terrible ordeal on the high sea. On the contrary, he resolves to be a better fisherman than he ever was. This is not the mark of one that has been defeated! It is the hallmark of a winner and that is why the hero of this novel stands at opposite ends with that of A Farewell to Arms.

The fact that Hemingway won the Nobel Prize for Literature one year after the release of The Old Man and the Sea (Wikipedia, http://en.wikipedia.org/wiki/ernest_Hemingway\#cite-ref-162, 2010) is also instructive in the value of this novel: such awards are won by those who by their works have contributed significantly to humanity. When a writer portrays characters in his work, he intends to pass a message to the rest of humanity through the characters and there is no gain overemphasizing the fact that of all of Hemingway's protagonists, the old man is arguably the most impressive: he epitomises the dogged determination and unwavering sense of focus needed for success. The fact that he goes without a catch for eighty-four days but never gives up is a clear pointer to this conclusion.

Apart from that, we learn a lot from the old man's refusal to succumb to self-pity and revel in charity, as many in his position would do, despite his extreme privation. That is why despite the fact that he relies on the boy for food, drinks and fishing bait, he does so reluctantly and pretends he does not actually need these things; not due to ingratitude but because he does not want to relapse to that comfort zone of living off charity. We are told that, "there was no cast net and the boy remembered when they had sold it. But they went through this fiction every day. There was no pot of yellow rice and fish and the boy knew this too" (10). However, both of them knew the importance of pampering one's ego as a means of self-motivation, and self-motivation is critical for worthwhile achievements.

Another significant lesson we learn from the Old Man's character is the need to focus on one thing at a time and avoid distractions. We see that the old man had gone for eighty-four days without a catch but it is on the day he makes the biggest catch of all time and is battling to subdue the fish that his other baits become major sources of attraction for fish in order to distract him from pursuing his main goal.

Sometime before daylight something took one of the baits and the line began to rush out over the gunwale of the skiff. In the darkness he loosened his sheath knife and taking all the strain of the fish on his left shoulder he leaned back and cut the line against the wood of the gunwale. Then he cut the 
other line closest to him and in the dark made the loose ends of the reserve coils fast.... Now he had six reserve coils of line (36)

There is much wisdom in what the Old Man has done here. What he is saying is that when pursuing a worthwhile target, one should avoid distractions no matter how tempting they might be lest you be torn in between. The Old Man is telling humanity that rather than divide your attention and be defeated, we should pool our resources and channel them towards the achievement of our main objective as he has done by cutting the ropes and joining them together to have reserve coils. The importance of focusing on the main objective of our pursuit is further demonstrated shortly after when Santiago allows himself to be distracted by a bird, "How did I let the fish cut me with that one quick pull he made? I must be getting very stupid, or perhaps I was looking at the small bird and thinking of him. Now I will pay attention to my work" (40).

\section{Conclusion}

From the foregoing, it is true that in Hemingway's works generally, man is confronted by a biological trap; a challenge inherent in man's nature that frustrates every of his efforts at attaining a good and comfortable life for himself. This is why we see all Hemingway's protagonists suffering and sweating against daunting odds placed in their paths to success both by man and, especially, by nature. However, the deciding factor is how we respond to that biological trap when we encounter it. It is that response that determines whether we succeed or fail, whether we are celebrated by our friends and foes alike or we are ignored as just another victim of the trap, fit only to be abandoned in the abyss of historical oblivion.

In the two novels under study, we have seen two such responses: whereas Frederick Henry of A Farewell to Arms has opted for resignation, Santiago in The Old Man and the Sea believes in the never-give-up spirit. When Catherine is in the operating theatre, Frederick sits outside and clothes himself in self-defeat and negativism

I sat down on the chair in front of a table where there were nurses' reports hung on clips at the side and looked out of the window. I could see nothing but the DARK (emphasis mine) and the RAIN FALLING across the light from the window. So that was it. The baby was dead.... I wished the hell I'd been choked all like that. No I didn't. Still there would not be all this dying to go through. Now Catherine would die. That was what you did. You died. You did not know what it was about..... (232)

Instead of seeing the light, he prefers to see darkness and with such a mindset, it is not surprising that Frederick Henry stands no chance against the biological trap that all Hemingway's protagonists encounter. That is why he does not only lose the child but also the love of his life.

However, the protagonist of The Old Man and the Sea refuses to yield to such nihilistic philosophy as Frederick Henry revels in. Even after going without a catch for eighty-four days, he refuses to see darkness; rather he sees the bright blue sky at its best even when he is all alone in a part of the sea where several other fishermen dare not venture into. That is why he catches the greatest fish of his life. When he catches the fish, he struggles with it for three days before he subdues and kills it. After he kills the fish, he begins the bitterest battle of his life, this time with the sharks which he fights till he tastes blood in his mouth. Through all this, his resolution is "...man is not made for defeat. A man can be destroyed but not defeated", (75).

This is the prerequisite for overcoming the biological trap that hangs over not just Hemingway's characters but all humanity.

\section{References}

Baker, C. (1964). Forum Lectures: The American Novel. Washington: U.S. Information Agency.

Benson, J. (1989). "Ernest Hemingway; The Life as Fiction and the Fiction as Life". American Literature Volume 61, Issue 3, 354-358.

Curry, D. e. (1988). Highlights of American Literature. Washington: U.S. Information Agency.

Desnoyers, M. F. (2011, November 30). John F. Kennedy Presidential Library Online Resources. Retrieved February 26, 2014, from John F. Kennedy Presidential Library and Museum.

Hemingway, E. (1952). The Old Man and The Sea. London: Heinemann Educational Books.

Hemingway, E. (1987). A Farewell to Arms. London: Grafton Books.

Marca, T. (December 11, 2010). "Characters Comming of Age in Ernest Hemingway's Works". Yahoo Contributor Network, $1-8$.

Mellow, J. (1991). Charmed Circle: Gertrude Stein and Company. Boston: Houghton Mifflin.

Meyers, J. (1985). Hemingway: A Biography. New York: Macmillan.

Wikipedia. (2010, March 7). http://en.wikipedia.org/wiki/ernest_Hemingway\#cite-ref-162. Retrieved February 27, 2014, from www.google.com.

Wikipedia. (2013, December 10). http://schools-wikipedia.or/wple/ernest_Hemingway.htm. Retrieved December 10, 2013, from www.google.com. 